\title{
WOMEN OF THE TWILIGHT: THE NARRATIVE SPACES OF WOMEN IN THE ICELANDIC RURAL COMMUNITY OF THE PAST
}

\author{
Júliana Th. Magnúsdóttir \\ Adjunct in Folkloristics \\ Department of Folkloristics, University of Iceland \\ jthm2@hi.is
}

\begin{abstract}
The article deals with some of the spatial features of women's storytelling traditions in rural Iceland in the late nineteenth century and early 1900s. The study is based on audiotaped sources collected by folklore collector Hallfreður Örn Eiríksson in the 1960s and 1970s from informants born in rural Iceland in the later part of the nineteenth century. The main focus of the article is on 200 women that figure in these sources and their legend repertoires, although a small sample group of 25 men and their repertoires will also be examined to allow comparison. The article discusses what these sources tell us about women's mobility and the social spaces they inhabited in the past. It goes on to consider the performance space of the Icelandic turf farm in which women's storytelling took place from the perspective of gender. After noting how the men and women in the sources incorporated different kinds of spaces into their legends, it takes a closer look at how the spatial components of legends told by the women reflect their living spaces, experiences, and spheres of activity. The article underlines that while women in the Icelandic rural community were largely confined to the domestic space of the farm (something reflected in the legends they told), they were neither socially isolated nor immobile. They also evidently played an important part in oral storytelling in their communities, often acting as the dominant storytellers in the performance space of the old turf farm.
\end{abstract}

Keywords: legends, narratives, performance, space, storytelling, the rural community of the past, women

In recent years, folklorists interested in folk narratives have started to find their way back to the folk narrative archives relating to the rural past, reviewing them with new approaches and methods in mind (see, e.g., Gunnell 2016, 2018; Rósa Porsteinsdóttir ${ }^{1}$ 2011; Skott 2008; Tangherlini 1994, 2013). These same folk narrative archives were largely abandoned by most folklorists in the latter half of the twentieth century in line with the new approaches in folkloristics 
which placed more value on the living performance event and fieldwork rather than archived texts, and on urbanised contemporary communities rather than on the rural communities of the past (see Gunnell et al. 2013). The general assumption was that the material contained in the archives represented "dead" text that had been collected as part of the faulty fieldwork efforts of the past, and that the apparent lack of contextual material made interpretation both questionable and unfeasible (Dégh 2001: 25; Honko 1989: 33). As I have argued elsewhere (Júlíana Póra Magnúsdóttir 2018), and will demonstrate in the following article, the folk narrative archives in question nonetheless represent vital sources that can still be used for a variety of purposes, and not least as part of the reconstruction of certain aspects of narrative tradition that were given comparatively little consideration in previous scholarship such as questions regarding gender and gender-roles and their influence on the formation and performance of women's narrative repertoires and narrative "spaces" that they reflect.

One aspect of this marginalisation of gender in earlier scholarship is the implicit assumption that rural women in the past were socially isolated, firmly rooted in the private domestic spaces of their homes, which may have led to their being assigned a secondary status in certain oral storytelling traditions. In Iceland at least, the oral archive materials demonstrate that this notion is oversimplified, not least with regard to women's geographical mobility in the past and the domestic space they inhabited on the farm. In Iceland, this domestic space was evidently a place where the private and the public effectively merged. It was also the centre of cultural production.

The key sources of my discussion will be the folk narrative repertoires of 200 Icelandic women born in the last decades of the nineteenth century, who were interviewed and recorded on tape by folklore collector Hallfreður Örn Eiríksson (1933-2005) in the 1960s and the 1970s. This material now forms part of the Folklore Audio Collection of the Árni Magnússon Institute in Icelandic Studies. ${ }^{2}$ This source material, which has its roots in the pre-industrial rural community of the Icelandic turf farm, includes not only oral narratives, but also a wide range of information regarding both the wider social context of women's storytelling in the past and the performance context in which their storytelling took place. As the focus of Hallfreður Örn's collecting efforts was predominantly on narrators born during the nineteenth century, his material effectively overlaps in time with that found in the written folk narrative archives (from the mid-nineteenth century onwards). His work thus provides valuable opportunities to fill in some layers of context that are often missing in the written collections. 
In this article I will, among other things, make some comparisons between the roles played by men and women as narrators on the Icelandic farms, as well as demonstrate some of the key differences that existed with regard to the performance contexts surrounding their performances. The article will start by considering the wider geographical space of Iceland and women's mobility within it, considering the roles of women as storytellers and the formation of their repertoires. The second part of the article will then deal with the actual performance space on the turf farm and differences that existed between men's and women's narrative performances. The last part will consider the narrative spaces reflected in the legends ${ }^{3}$ told by the women compared with those found in men's narratives, demonstrating how women evidently incorporated their living spaces and experiences into their narratives.

\section{THE WIDER GEOGRAPHICAL SPACE: WOMEN IN ICELAND}

In Iceland, the pre-industrial rural community was largely characterized by a lack of infrastructure, unpredictable nature, dispersed settlements and an absence of what has become known in modernity as public spaces. Until the early 1900s, the farm was the centre of both social organization and cultural production and to a large extent a self-sufficient economic unit. The farm's social organization was thus not only shaped by socially constructed gender roles and norms, but also by particularly harsh environmental conditions that placed restrictions on social interactions outside the realm of the farm for most of its inhabitants and for women in particular. In this community, men were almost exclusively responsible for managing the external affairs of the farm and undertaking seasonal travels, like those relating to fishing and commerce. The general confinement of women to the domestic space of the farm raises some important questions about their key role in the transmission of oral narratives in Iceland. Did the more limited mobility of women in the past mean that they played a lesser part in the migration of oral stories?

It is important to first address the common assumption that in the past women did not generally travel between communities as much as men in Iceland. This argument needs some refining. Until the early 1900s, so-called orlofskonur (holiday women) were common guests on Icelandic farms during the autumn, just before the cold winter set in. These were predominantly older women who had limited household responsibilities or had passed them on to younger women in their households, leaving themselves with spare time to travel and socialize with relatives, friends, neighbours, and their former masters. Many of these women belonged to the lower economic strata and this led to some 
people viewing their visits as thinly-disguised begging trips, since according to custom, the housewife on the host farm was expected to reward a guest with generous parting gifts (Jónas Jónasson 2010: 249-251). Understandably, as the tradition of orlofsferðir (holiday journey) gradually came to an end in the early 1900 s, none of Hallfreður Örn's female informants were active participants in this custom. Orlofskonur nonetheless evidently played a prominent role in the storytelling tradition if we trust women's accounts of storytelling in their childhood and their narratives about gifted storytellers and their storytelling sessions, some of which even imply that storytelling was the primary purpose of the women's visits. ${ }^{4} \mathrm{~A}$ good example of this can be seen in the following account told by Ástríður Thorarensen (1895-1985) about the storytelling of a woman called Guðrún, who visited her childhood home every fall in the early 1900s:

I came to Breiðabólsstaðir in 1900. And she came every autumn and told stories. Naturally mainly to the children, but everyone listened, everyone who wanted to hear, because they enjoyed listening to her telling them. And this went on for many years. She died in 1911 and did it right up to that point in time, I think she came last in 1910. She told us the same stories. Naturally we asked for them.

You wanted to hear this one or that one, and there were some stories that were told more often than others ... "Kisa kóngsdóttir" [Kisa, the King's Daughter] and "Porsteinn glott" [Smirking Porsteinn] and "Hnoðri" [Wispy], and "Álagaflekkur" [Enchanted-Spotty] and "Rautt hnoð" [Red Ball] ... [On supernatural legends:] I never heard her tell such stories ... She sat and talked with the householders, and then various things came up, of course, various kinds of information as tends to happen. They talked about people and things, and then of course there would be some verses and this and that, as usual, as part of a conversation. ${ }^{5}$ (SÁM 89/1793).

The prominent appearance of such orlofskonur in narratives about storytelling not only underlines that some women did indeed travel in Iceland's rural past, but also the degree to which women played an active role in the distribution of narratives between communities. In a sense, these women can be regarded as having been professional storytellers in pre-industrial rural Iceland, since they cultivated their storytelling skills as a means of gaining both economic and social capital.

The second feature worth considering here is the effect of women's permanent migration between communities on the transmission of oral narratives. The cultural influence on the oral tradition of people moving to different parts of Iceland as a result of marriage or work has rarely been addressed by scholars 
dealing with similarities in narratives within the tradition or the geographical scope of migratory legends in Iceland. Most scholars have tended to explain such similarities with reference to the traditional seasonal work-related travels back and forth across the country by fishermen and other seasonal workers and to the recurrent journeys undertaken by men to trading centres (Almqvist 2008: 314; Gunnell 2002: 205; 2004: 61; Trausti Dagsson 2014: 7-8). Discussions of this kind usually focus on the world of male experience and seasonal male mobility, leaving unanswered questions like those relating to the role of men in the transmission of Icelandic migratory legends dealing with women's experiences, their points of views and their social roles. ${ }^{6}$ It would arguably be more logical for such stories to be attributed to women, and for their movement from one community to another to be the result of women moving between communities for marriage or work. While such a migration of women might have been less regular, it was nonetheless a common feature of the Icelandic rural community, partly because deep-seated patriarchal traditions up into the twentieth century tended to prioritise the male inheritance of farmland, something that led to men rather than women remaining in the communities of their youth after marriage, often taking a spouse from another community (Hjördís Sigursteinsdóttir \& Guðbjörg Linda Rafnsdóttir 2009: 33-39). In short, while men may have travelled on average more than women in their everyday lives, women were arguably more prone to move their long-term residence to new communities, naturally taking their legend repertoires with them.

Table 1. The number of women storytellers classified on the basis of the size of their repertoires and residential history.

\begin{tabular}{|l|l|l|l|}
\hline $\begin{array}{l}\text { Repertoire size } \\
\text { (number of legends told) }\end{array}$ & All women & $\begin{array}{l}\text { Women remain- } \\
\text { ing in childhood } \\
\text { regions }\end{array}$ & $\begin{array}{l}\text { Women settled } \\
\text { in new regions }\end{array}$ \\
\hline $1-9$ & 128 & 76 & 52 \\
\hline $10-19$ & 47 & 23 & 24 \\
\hline $20-29$ & 13 & 6 & 7 \\
\hline $30+$ & 12 & 3 & 9 \\
\hline Total number of women & 200 & 108 & 92 \\
\hline & & & \\
\hline
\end{tabular}

The biographies of the 200 female legend tellers that lie behind this study provide a valuable insight into the scale of the long-term movement of women in the late nineteenth century and early $1900 \mathrm{~s}$, as well as the influence that this might have had on women's legend repertoires. As can be seen above, close to half of these women ( 92 of 200 , see Table 1$)^{7}$ migrated in adulthood away from 
the region they grew up in, many settling down in their husbands' childhood communities. Some of these women even undertook frequent movement between communities (see Table 2), in some cases moving long distances, meaning that they experienced ways of life in very different parts of Iceland. The effects of women moving their place of residence on the size of their legend repertoires become particularly evident if we compare the repertoires of the women who moved to different parts with those of the women who lived most of their adult lives within the regions in which they grew up. While the former group constitutes only $46 \%$ of the overall total of 200 women storytellers in the sources, they make up more than half of the number of more active legend tellers who tell 10-19 and 20-29 legends (see Table 1) and 75\% of those exceptional legend tellers telling 30 legends or more. This underlines the strong correlation between the geographical residential changes undertaken by women and the size of their repertoires.

Table 2. The number of moves undertaken by the 92 women who settled outside their childhood regions as adults examined in relation to the size of their repertoires.

\begin{tabular}{|l|l|l|}
\hline Number of women & $\begin{array}{l}\text { Number of moves between } \\
\text { regions }\end{array}$ & $\begin{array}{l}\text { Average number of stories } \\
\text { in repertoires }\end{array}$ \\
\hline 21 & 1 & 10.9 \\
\hline 28 & 2 & 11.1 \\
\hline 18 & 3 & 12.8 \\
\hline 12 & 4 & 15.5 \\
\hline 9 & 5 & 16.9 \\
\hline 2 & 6 & 9.5 \\
\hline 1 & 7 & 21.0 \\
\hline 1 & 8 & 34.0 \\
\hline
\end{tabular}

A good example of an active legend teller who experienced life in many different communities in Iceland is Geirlaug Filippusdóttir (1876-1970), who told a total of 21 legends in her interviews (SÁM 86/826-32; 86/847-48). Geirlaug left her home farm in Fljótshverfi in southeast Iceland at the age of nine to work for two years as a babysitter at her uncle's farm in Hornafjörður, about 150 kilometres east of her childhood home. At the age of 16 , she then left her family in Fljótshverfi again to become a maid at the local sheriff's household some 30 kilometres away. Four years later, she moved about 200 kilometres east, and became a farmhand on a farm close to Hornafjörour in the east of Iceland where she lived until the year 1900 (the age of 24). By that time, her family had also moved across the country to settle down on a new farm in Borgarfjörður Eystri, 
more than 400 kilometres east of their old home in Fljótshverfi. After briefly joining her family there in 1900, Geirlaug went on to become a farmhand in the neighbouring fjord, Seyðisfjörður, where she worked as farmhand until 1904. At that point in time, she married a farmer's son from Breiðdalur in eastern Iceland, this time moving some 100 kilometres back south in order to settle down on her husband's childhood farm. After becoming a widow in 1924, at the age of 48 , she moved once again, this time travelling about 600 kilometres southwest to the growing capital of Iceland, Reykjavík, where she lived for the rest of her life (Björn Magnússon 1970: 307).

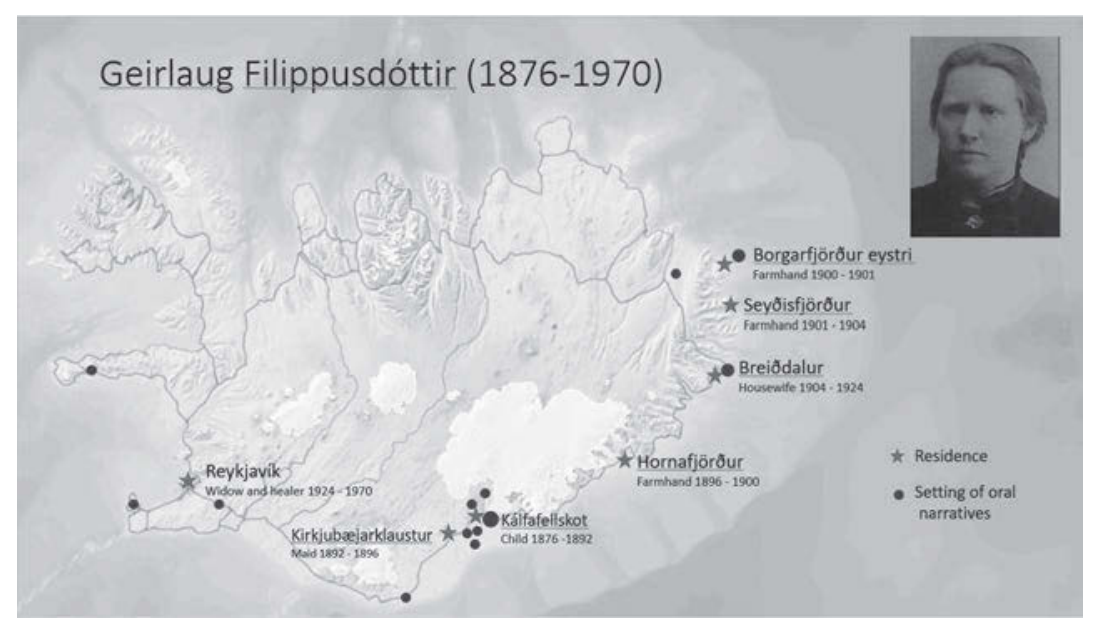

Figure 1. The residence of Geirlaug Filippusdottir and the setting of her oral narratives.

As can be seen from the above, there is little question about Geirlaug's geographical mobility, even though she would have been largely confined to the domestic space of the farm in each of her successive roles as a female farmhand and later as a housewife. It is also worth bearing in mind that since she lived for relatively long periods of time in each of her new communities, rather than just visiting them briefly as a traveller, she was in a particularly good position to become an active participant in the local legend tradition, constantly gaining new interested audiences for her repertoire and new opportunities for expanding this repertoire as she adopted narratives and traditional ideas from each of her new communities. While Geirlaug predominantly tells first- and second-hand memorates about her own experiences and those of her family, drawing on the localized supernatural traditions surrounding the various homes she lived in 
during her lifetime, she also appears to have incorporated some narratives into her repertoire that originated with non-related people she came across during her frequent movement between communities. These include the story of an elf woman, which she heard from the sheriff she worked for in Kirkjubæjarklaustur; stories of the murderer Axlar-Björn, which she heard from old women in Hornafjörður when she was working as a babysitter there; and a story of the Lagarfljót serpent, which she heard from a woman who stayed at her home in Breiðdalur.

While the women's residential histories are an important key to understanding their role in the storytelling traditions of the past and in the transmission of narratives from one area to another, they do not always say much about exactly where these women told their stories or from whom they learned their legends. The recordings nonetheless often provide some important clues about such things since Hallfreður Örn frequently asked his informants about the previous narrators of the legends they told him. With regard to the roughly 2200 legends told by his 200 female informants, about 730 are accompanied by important contextual information of this kind. About $65 \%$ of the previous narrators are family members, and most often the women's mothers. ${ }^{8}$ Nonrelated members of the household are then cited as the sources of about $10 \%$ of these legends, ${ }^{9}$ underlining the fact that Icelandic rural households in the past were rarely strictly private spaces inhabited by the family alone. All the same, the fact that a total of $75 \%$ originated with household members underlines the degree to which Icelandic households were the primary platform for storytelling in the past.

Nonetheless, the fact that the women appear to attribute the other c. $25 \%$ of those legends to friends and neighbours from outside the household underlines that despite their general confinement to the domestic space of the farms, these women must have had at least some social networks that extended beyond their households. In this regard it might be born in mind that farms (and especially the living room on the farm) were in most cases the only available places for any small or large social gathering to take place (not least storytelling), until special community houses started to appear in rural Iceland in the 1910s-1920s (on Icelandic community houses see Jón M. Ívarsson 2007: 70-73; Loftur Guttormsson 2008: 60-61.) During the winter season, it was the baðstofa (living room) that tended to be the scene of traditional cultural work-related events, such as the so-called kvöldvökur (lit. evening wakes; sing. kvöldvaka) (Magnús Gíslason 1977) which, along with the activities of the so-called rökkrin (lit. the twilight gathering, referring to the period in the evening before the kvöldvökur took place) was the primary context for both Icelandic oral storytelling and other cultural practices. 


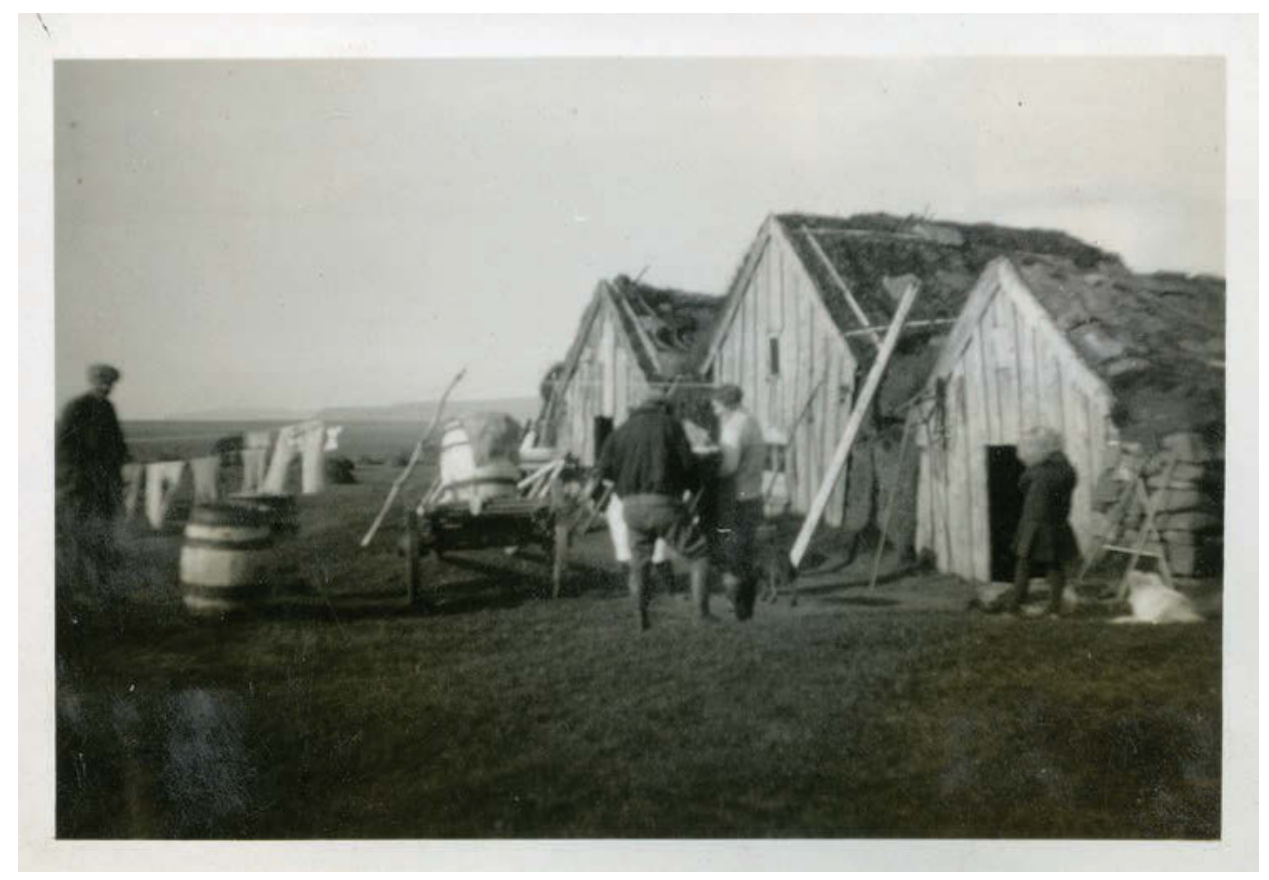

Figure 2. An Icelandic turf farm in the early 1900s. Photograph courtesy of the National Museum of Iceland.

\section{WINTER-NIGHT STORYTELLING IN THE BA円STOFA}

Storytelling traditions in the baðstofa were to a large extent shaped by two key factors. The first one was associated with the social organization of the community that had a natural influence on participation in the different cultural practices that took place on the farm. The second factor was related to the nature of the baðstofa space itself, which not only determined which forms of cultural entertainment could be performed at any one time but also the ways in which it was received and experienced by the audiences. Together these features provide the performance context of the storytelling, something to which Hallfreður Örn paid particular attention in the material that he collected, which sheds valuable light on the place and role of women in these events. As I will show below, cultural performances in the winter nights in the baðstofa had two distinct and different settings that distinguished themselves on the basis of the gender of those involved and the fact that they had quite a different atmosphere.

Icelandic archaeology and ethnography provide an abundance of contextual information not only about what the baðstofa would have looked like in the 
past, but also on its function and on its historical development throughout the centuries. In short, the Icelandic turf farm involved a cluster of interconnected houses built from turf, stones, and wood, which were connected by a long tunnel that started at the front door and usually ended at the heart of the farm, the so-called baðstofa, the communal living room where most residents both worked and slept (Anna Lísa Rúnarsdóttir 2007; Hjörleifur Stefánsson 2013; Guðmundur Ólafsson \& Hörður Ágústsson 2004; Boucher 1989: 43, 59-60, 119-120, 181). From the early 1900s and onwards, these turf farms were increasingly replaced by more modern houses built of timber and, later, concrete, first of all in the newly emerging fishing villages but later on also in the rural countryside. In 1910 , around $52 \%$ of all Icelandic houses were turf houses (around 74\% in rural areas), but in 1940, the number of such houses had been reduced to around $11 \%$ of all Icelandic houses (23\% in rural areas) (Guðmundur Jónsson \& Magnús S. Magnússon 1997: 3003-3011). The multi-bedroom houses that replaced the turf farm naturally transformed people's perception of space, access to privacy, and people's interaction on a daily basis, making this change in architecture a fundamental factor in the cultural transformation that took place in Iceland in the twentieth century.

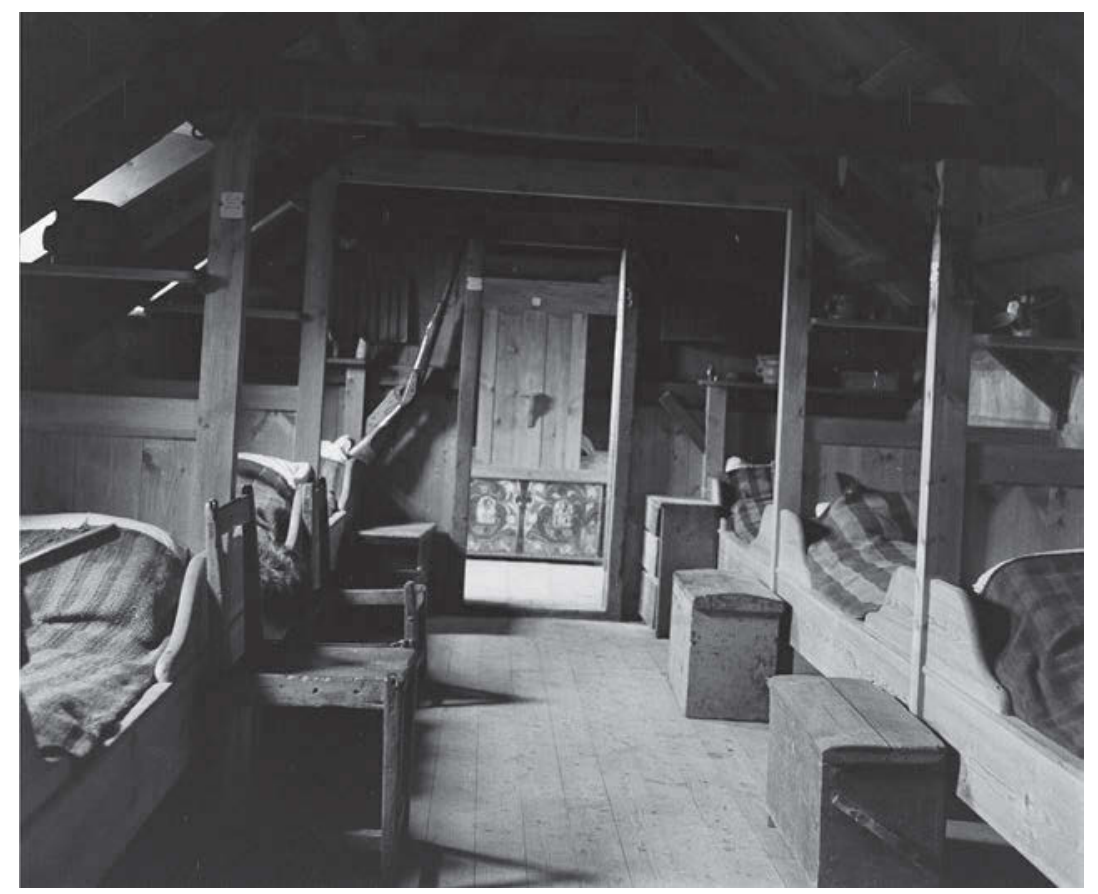

Figure 3. Baðstofa at Glaumbær in Skagafjörður. Photograph by Guðni Pórðarson, courtesy of the National Museum of Iceland. 
As suggested above, the baðstofa was not only a gender-mixed communal space in which families lived in close and intimate contact with non-related workers and guests but also a space in which home life and the workplace merged (especially in the wintertime). The multi-sided nature of this performance space makes it a particularly challenging and interesting place to explore, not only from the viewpoint of the physical surroundings of oral storytelling but also the gender dynamics involved. The cultural scene and atmosphere of the baðstofa would traditionally change depending on the season, the time of the day, and work rhythms of the household members. The winter season in particular had its own rhythm within the baðstofa, a tradition that was comparatively fixed and deep-rooted in the rural community of Iceland. Division of labour on many Icelandic farms during the winter was both conventional and seasonal, adult male household members traditionally looking after the sheep during the first part of the winter, and often leaving for the fishing season in January, which meant that on many farms the farm work was then left in the hands of the women until the spring (Gunnar Karlsson 2000: 106-110; Magnús Gíslason 1977: 47). The period from September until the men of the household left for the fishing stations in January was particularly important for cultural activity on the farm, with various forms of oral performances taking place during the rökkrin and later the kvöldvaka.

Sources suggest the setting that characterized the rökkrin offered particularly good opportunities for oral storytelling. The term rökkur refers not only to the time setting but also to a particular atmosphere in the baðstofa caused by the length of the Icelandic winter twilight and the fact that fuel for the lamp needed to be economized. This is the time of the day when the men came in from outside and when many adults used the opportunity to take a nap referred to as rökkursvefn (twilight sleep). During this time, low-key storytelling would often take place in one corner of the baðstofa for children, teenagers, and other household members who did not need the sleep (Magnús Gíslason 1977: 70-72, 149-150). This particular period of storytelling had a practical purpose: in bad weather, the children could not be sent outside to play but had to be kept calm and quiet while the adults slept (Magnús Gíslason 1977: 144; SÁM 86/888 (Sigríður Helgadóttir); SÁM 89/1717 (Helga Porkelsdóttir Smára)). According to many of Hallfreður Örn's informants, this setting was the most common scene of oral storytelling on the turf farm, well over 50 accounts either making this claim or containing descriptions of such storytelling sessions. ${ }^{10}$

Over and above its practicality as a means for keeping children under control, another possible reason for why rökkrin might have become a preferred platform for oral storytelling is that the semi-darkness (like that in a theatre) provided a good means for the audience to transfer themselves mentally from 
the immediate living space to that of the narrative. The darkness, the need for quiet and the sound of people sleeping would also have helped create a real or false sense of intimacy, confidentiality and community spirit or communitas (Schechner 2006: 70-71) among the storyteller and his or her intended audiences. The darkness naturally also provided storytellers with a degree of freedom from the visual gaze of audiences, which may have been helpful for modest or less self-confident narrators. One account by Ingibörg Tryggvadóttir (1904-1986) (SÁM 88/1546) is particularly interesting in this respect, as it describes how in her youth young people used to take part in meetings organized by the local youth movement in order to practise public speaking. She notes that a common practice during these sessions was for the light to be turned off to help those who felt shy and insecure when speaking.

Sources suggest women rather than men were the dominant storytellers during rökkrin. In Hallfreður Örn's sources, women, especially old women, are referred in this context nearly four times as often as men. ${ }^{11}$ The logical explanation for this can be found in the traditional division of labour on the turf farm noted earlier, in which men, and in some cases younger women, tended to be responsible for physically challenging tasks and outdoor work and therefore had greater need for sleep at twilight. Further support for the strong role of women in these activities is found in the work of those scholars who have dealt with the Icelandic wonder tale tradition, such as Einar Ólafur Sveinsson (2003: 69) and Rósa Porsteinsdóttir (2011: 66; 2015: 70-71), both of whom have shown that women had a much larger role in the preservation of this tradition than men in the late nineteenth century and early 1900s. This may well have been a result of their key role as the predominant entertainers during rökkrin.

Another aspect of the baðstofa storytelling revealed by Hallfreður's sources relates to exactly what was being told and to whom. It seems evident that the nature of the audience in the baðstofa during rökkrin had some influence on the genres chosen, as well as notions of what it was considered appropriate to tell. As noted above, the predominant audiences of rökkursögur (e. twilight stories) tended to be children and teenagers. Those informants who describe the rökkrin storytelling sessions note that, as might be expected, wonder tales were indeed common. However, they also mention that legends were told as well as retellings of stories in literature or others based on rimur poetry (a form of ballad, see Ragnheiður Ólafsdóttir 2008). Genre classification of the material is complicated by the fact that informants rarely use scholarly classifications for oral narratives, such as æuintýri (wonder tales) or sagnir (legends). Instead, they talk about "stories about kings and queens", "stories of ghosts and huldufólk" (hidden people), ${ }^{12}$ or "stories of events in the past". If one connects such "ethnic classifications" to our modern scholarly genres, it is apparent 
that in the accounts about rökkursögur, 23 contain clear references to wonder tales, and 30 to legends, while 14 just mention unclassifiable sögur (stories). Four mention stories based on books or rimur verses. One old woman in the childhood home of Sigríður Guðmundsdóttir (1893-1975) is said to have told folktales and stories "from her own life" and "from Ísafjarðardjúpur where she grew up" (SÁM 89/1812).

Some legend topics seem to have been more controversial than others. The grandmother of Helga Porkelsdóttir (1884-1974) apparently told both wonder tales and legends of outlaws and huldufólk during rökkrin, but rarely ghost legends, since she did not want the children to become afraid of the dark (SÁM 89/1717). This attitude is reflected by a number of other informants ${ }^{13}$ as well as in other sources on storytelling in the baðstofa (Magnús Gíslason 1977: 71). In spite of this, legends about ghosts seem to have been one of the most common features of storytelling during rökkrin, or at least among the most memorable ones. This topic is commonly cited in the accounts about these storytelling sessions, followed closely by legends dealing with the huldufólk. ${ }^{14}$ Ghost legends evidently had a somewhat ambiguous status in the oral tradition of the turf farm (especially in the rökkrin sessions), something that is understandable considering the general living space and the atmosphere which would have amplified the emotional effect of ghost stories. As reflected in the following account about storytelling by Júlía Sigríður Guðmundsdóttir (1896-1982) in Hvítanesi in the early 1900 s, the baðstofa surrounded by a maze of dark narrow corridors could become a fearful place during the twilight:

We became so afraid of the dark that my father and mother didn't want to tell us such stories, because then we didn't dare leave the baðstofa. They were telling us these things, and we were sitting in our beds in the baðstofa with our feet up on the bed because we thought that this thing might come out from under the bed. It was a pity that grandmother died because she would have told us that sort of thing, sometimes in the rökkrin. (SÁM 89/2048)

As noted above, it is evident that these storytelling sessions for children and teenagers were not the type of spontaneous and dynamic conversational storytelling event commonly associated with legend sharing but rather organized, conscious, time-bound performances that usually involved only one narrator and a particular designated space in the corner of the baðstofa. It is nonetheless also clear that other kinds of less structured storytelling sometimes took place in the baðstofa during the rökkrin, especially in those households where twilight sleeping was not practised. These sessions tended to be less gender- 
specific in terms of narrators and also more skewed towards legends than wonder tales since the intended audiences involved adults rather than children. An account by Porsteinn Guðmundsson (1895-1984) tells about such storytelling in a baðstofa in south-eastern Iceland in his youth, in which they "would sit there and remember old events and tell stories rather than have a nap" and his parents "asking each other ... about things that happened in their youth" (SÁM 85/228).

The work-related session of kvöldvaka that followed on closely from rökkrin, also had an equally important role to play in the farm's cultural activity. If we compare the performances that took place in rökkrin with those that occurred during the kvöldvaka later in the evening, it is evident that the latter involved not only a completely different setting but also different genres, a different atmosphere, and a different gender of the performer. As noted by the Icelandic historian Guðmundur Hálfdanarson (2008: 116-117), the lighting of the kerosene lamp at the beginning of the kvöldvaka signalled the transformation of the baðstofa from a space which was broken up into separate spheres into one that represented an undivided communal space or workplace. Traditionally, one member of the household, situated under the lamp in the centre of the baðstofa, would be given the task of reading or performing in some other way during the kvöldvaka for the other members of the household who would be working with wool or be engaged in other tasks (Magnús Gíslason 1977: 88-90). Many of Hallfreður Örn's informants who consider the nature of the kvöldvaka note that it was more often men than women who now assumed the role of presenters, citing various reasons for this, such as the fact that work-related noise sometimes drowned out women's voices (SÁM 90/2341; 86/834; 89/1967, 90/2287) or that men were simply too tired to take on any further physical work during the kvöldvaka (SÁM 86/812). ${ }^{15}$

Two other features that distinguished the kvöldvaka from rökkrin were the actual mode of performance and the nature of the genres performed. While oral storytelling did occasionally take place during the working session, especially when guests were staying overnight, by far the most dominant form of entertainment involved reading books out loud, primarily the Old Icelandic sagas and the newly published Icelandic novels. Also popular in these performances was the chanting of the rimur poetry. ${ }^{16}$ The atmosphere was also naturally different, shifting from the dark, mystical and supernatural atmosphere of the intimate rökkrin to the broader oil lighting and more secular, rational atmosphere of Icelandic literature and the rimur tradition.

It is thus evident that the storytelling platform of the baðstofa was coloured by both the physical nature of the room and of the gender-roles that existed on the farm. While the social organization of the turf farm appears to have 
largely favoured women rather than men as oral storytellers, during the late nineteenth century and early 1900 s, this role of storytelling seems to have been predominantly assigned to the semi-dark hours of rökkrin. Once the lamp was lit, however, it is evident that the baðstofa was transformed into a wholly public workplace that was essentially dominated by male performers and more literary traditions that emphasized rationality and enlightenment, in other words, largely profane genres of performance. Even here, within the shared performance space of the baðstofa, one thus witnesses the familiar pattern of women being relegated to performing in a more private space.

\section{THE NARRATIVE SPACE}

The third type of space worth considering in relation to women's legend-telling is the spaces reflected in the legends they tell. As underlined below, legends are not only told in space but also, to a large extent, incorporate the space(s) that were daily inhabited by their narrators. As has been shown by the British folklorist Terry Gunnell, both wonder tales and legends have the capability to transform space, albeit in a different manner. Legends, of course, tend to be closely bound up with the living spaces inhabited by narrators and their audiences. At the same time, Gunnell argues, they might be said to add new temporal depth, characters, and mystery to these surroundings, simultaneously offering guidelines for listeners on how to deal with these surroundings and the animate and inanimate threats they incorporate (Gunnell 2006: 13-15). Legends that are bound up with space familiar to both narrators and their audiences thus add layers of meaning and values to these spaces. In this sense, legends are an important tool in the making of "places", effectively transforming unmarked and unbound spaces into meaningful and familiar places (cf. Tuan 1977: 85-100) in the minds of their narrators and listeners. They also underline the fact that while local geography and physical spaces are essentially gender-neutral, people's experiences of them are not. While, as has been shown above, many Icelandic women were certainly mobile (albeit in a way different from men), and while the domestic space of the farm was the dominant place of economic and cultural production for both men and women, the traditional division of labour on gender lines meant that both men and women would naturally have had different experiences of the various social spaces, both on the farm and in its wider surroundings.

One of the biggest weaknesses of folk narratives being published as part of "national" collections, often as a result of the earlier forces of romantic nationalism, is that their original, very real connection with the local surroundings 
of their narrators often gets lost. The same applies to the implicit connections they often have to the gender of their narrators and their worlds. In reality, comparatively very few Icelandic legends (even those that appeared in the early "national" collections) appear to have been shared nationwide. This becomes particularly evident when one examines the geographical and spatial features of the legend repertoires of the women interviewed by Hallfreður Örn, as well as those found in other narratives told by women (Gunnell 2016: 30-33; Trausti Dagsson 2014; Júlíana Póra Magnúsdóttir 2008b: 165). As noted above, the 200 women interviewed tell a total of little above 2,200 legends, of which only about $17 \%$ have an unspecified setting or a setting that has no apparent connection to the narrator's residential history. Furthermore, it seems evident that the region in which the women grew up regularly plays a particularly large role in these repertories, $70 \%$ of the narratives taking place in the area in which they lived as children. This underlines the fact that Icelandic legend traditions tend to be highly localized, focusing on places that were familiar to the narrators and their audiences. It also underlines how migratory narratives tend to be adapted to fit local circumstances.

The strains of the gender-restricted roles and environmental conditions that were experienced by Icelandic women in their everyday lives are also reflected by the geographical scope and nature of the legends that they told. As has been shown by studies dealing with the geographical aspects of legend repertories of male Icelandic narrators in the past, the settings of their legends are commonly associated with the routes that they travelled and the places outside the farms in which they worked, while the legends told by women tend to be associated with the domestic space of the home and its local surroundings (Júlíana Póra Magnúsdóttir 2008a: 755-757; Trausti Dagsson 2014: 8-9; Gunnell 2016: 30-32). In short, while men and women certainly shared many aspects of the Icelandic legend tradition, and while their legends were shared with audiences of both genders during storytelling sessions such as those in the baðstofa, it is evident that the legends told by most women in the past were generally less diverse in terms of setting than those told by men.

This spatial feature is reflected quite clearly in the legends told by the women interviewed by Hallfreður Örn Eiríksson. If one breaks down the general patterns relating to the settings and narrative spaces in the roughly 2,200 legends told by women and compares them to the patterns reflected in the legends told by a small sample group of men in the same sources (see Fig. 4), it becomes evident that the emphases are somewhat different as the studies noted above have shown. Women's legends appear to revolve noticeably more around the indoor and outdoor spaces of the farm itself than those told by men. This is, of course, understandable, given the fact that the farm and its indoor spaces were 
not only the main living space inhabited by women, but also their predominant working space. In short, the legends told by women tend to reflect the lives and concerns of those who tell them.

The most noticeable difference between men's and women's uses of spaces in their legends is seen in the occurrence of what might be termed "the wilderness", that is, the uncultivated spaces between settlements, such as the highlands and the sea. It is noteworthy that these types of spaces are far more common in legends told by men, underlining the fact that in rural Iceland in the past, the wilderness belonged predominantly to men's sphere of activity and experience. While it does still occur as a setting or part of a setting for about $34 \%$ of the legends told by women, there is also a significant difference in how men and women make use of the wilderness as a setting in their stories. The women's standpoint here is often more complex, often less focused on the event in situ. One can take as an example the following two narratives about an accident at sea, the one on the left being told by a man, Jóhannes Magnússon (1877-1970), while the one on the right is told by a woman, Lilja Björnsdóttir (1894-1971).

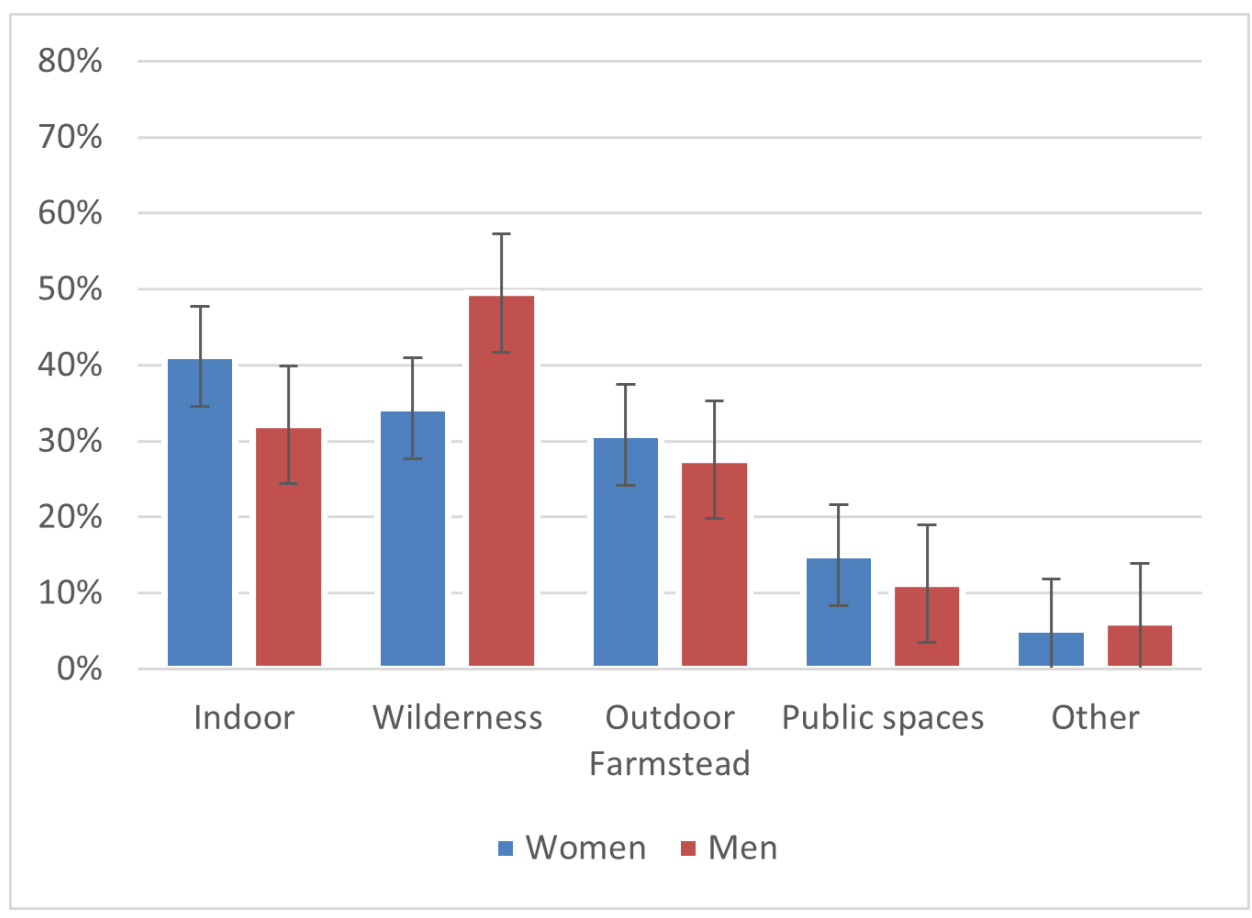

Figure 4. Types of spaces occurring in legends told by women ( $N=2235)$ and men $(N=196)$. The error bar shows the standard error. 
I knew the foreman of a boat who rowed out from the same place as me, from Guðlaugsá, out there in Ströndin. I was rowing out from there for two fishing seasons. And there was a man there who lived in the western fjords, who was called Guðmundur Benediktsson, and was a great fisherman. $\mathrm{He}$ never failed to catch anything, never. Well ... there was this rock on the way out from Eyrar to Núpir, which was covered in water at high tide and visible when it was low. But it was a sure place for fish, in front of the rock. I was fishing out there two seasons and nothing ever happened, I was always careful to keep to deep water. Otherwise you could end up on top of the rock, but that never happened. But one time this Guðmundur came along with a large catch of ocean quahaug from Staðareyrar, he was in a group with other men. There were six men in a boat packed with ocean quahaug, and they got stranded on the rock and all of them drowned there.

That was a real tragedy. (SÁM 90/2323)
The night the lightship

Hermóður sunk in bad weather, just out from Reykjanesröst

I think it was, it went down on the way from the Westmann Islands to Reykjavík, I remember it well. That same night I dreamt of my husband who had died long before but had been on Hermóður for some time, and he said: "Can you put my clothes together because I'm going on board Hermóður?" He had known about this, he had known that Hermódur was going to sink because he had been on the lightship Hermódur for some time before. (SÁM 89/1913).

Unlike men, who commonly take a secular approach to such accidents and stick to the course of events that take place at sea, women tend to take a different standpoint and often draw on the supernatural tradition in such narratives, and especially dreams that take place at home. Dream narratives, such as the one 
given above, are by nature multi-spatial and provide women with opportunities to transcend the more limited physical space they inhabit and participate in narrative themes dealing with important events and places to which they otherwise have little physical access. These kinds of dream narratives, which usually take the form of memorates, seem to be particularly common in the repertoires of those women who moved to new communities as adults, sometimes allowing them narrative access to contemporary people and events that take place in their former childhood communities which are now physically/ geographically distant. ${ }^{17}$

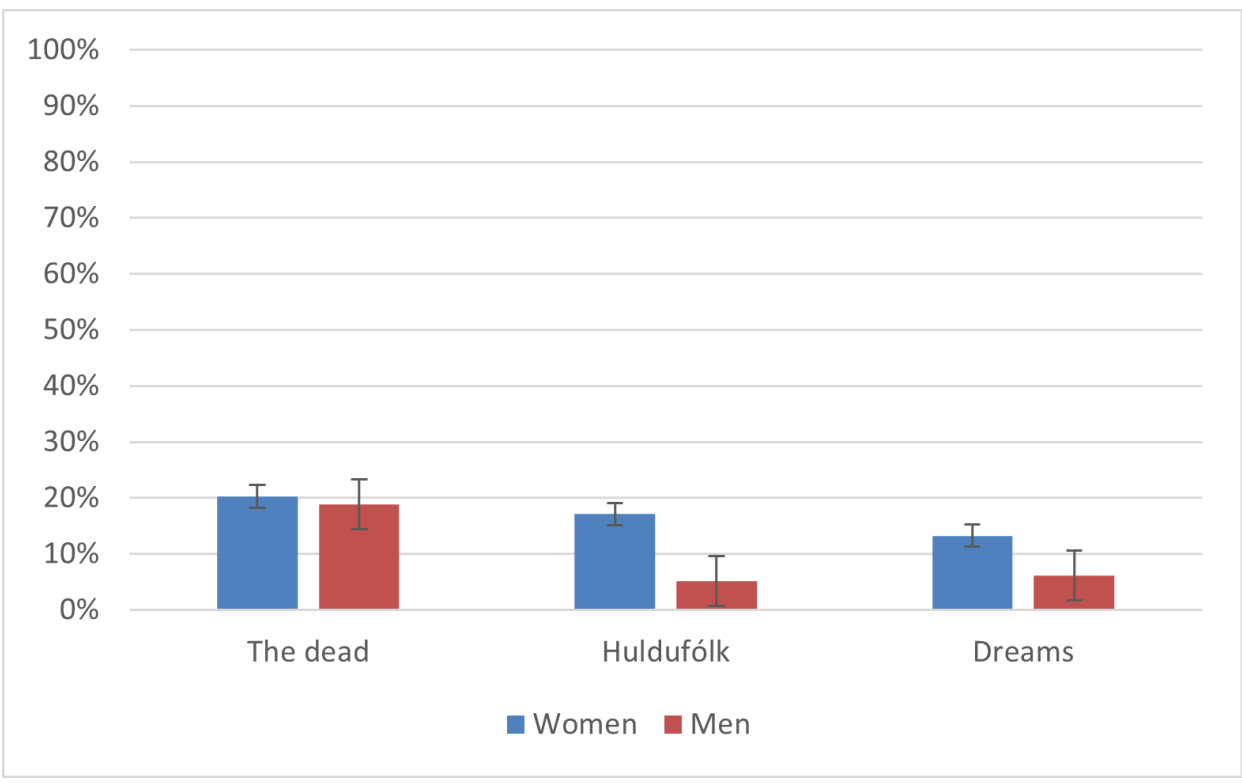

Figure 5. The occurrence of three different supernatural themes in legends told by women $(N=2235)$ and men $(N=196)$. The error bar shows the standard error.

Another aspect of folk belief that forms a feature of women's narrative traditions and is directly related to their living spaces is reflected in the types of supernatural beings that appear in their stories. As Kristen Hastrup, a Danish anthropologist, has shown in her analysis of perceptions and world views in the 
Icelandic turf farm community (Hastrup 1990: 255-265), Icelandic folk belief traditions in the past had an essential spatial component, in that different types of supernatural beings were assigned to different kinds of environment. ${ }^{18}$ Trolls, outlaws, and sea and lake monsters belonged to the wilderness outside the cultivated surroundings of the farm, while the huldufolk were usually situated in close proximity to the farms themselves, in the rocks and hills that formed a border between the wilderness and the cultivated land of the farm. The dead, however, even though they were evidently seen as inhabiting their graves, were perceived as being spatially independent, and capable of moving around at will.

This spatial component is particularly worth bearing in mind when applied to the supernatural themes encountered in legends told by women and their male counterparts. The largest group of supernatural themes in legends told by both men and women are the dead, which appear at a similar rate in the legends of both sexes. There is, however, a difference in the kinds of ghosts that occur in these legends. On closer examination, about half of these legends told by women deal with so-called ættardraugar (family spirits), revenants that haunt families for several generations, typically making themselves evident in the domestic space of farms visited by the unfortunate family members (on ættardraugur see Gunnell 2012). In short, the ættardraugar tradition has a particularly strong spatial connection to the space inhabited by women, which may explain why these figures appear so frequently in women's legend repertoires.

The second largest category of supernatural beings to appear in the legends told by women are the earlier noted huldufólk, who appear in about $17 \%$ of the legends. It is interesting to note that while women appear to tell a similar number of legends about the dead as their male peers, they appear to be far more interested in the huldufólk who only account for about $5 \%$ of the legends told by men in the same sources. This gender-misbalance (the huldufólk appearing more than three times as often in women's tales than in those of men) suggests that to some degree the huldufólk were perceived as being more closely associated with women than men (on this, see also Gunnell 2018). As with the ættardraugar, this might be seen as being quite logical considering the fact that the world of the huldufólk was so closely connected to the cultivated life of the farm, the well-being of the farm being closely bound up with the maintenance of good relations with these supernatural beings.

Indeed, there are many signs that the narrative tradition associated with the huldufólk was predominantly shaped by women. As has been underlined by several scholars working on this topic in the Icelandic legend tradition (see, e.g., Almqvist 2008: 273-342; Guðrún Bjartmarsdóttir 1982: 319-336), legends 
dealing with the huldufólk tend to deal with domestic issues usually associated with women, such as childbearing, farming, the securing of food and other household issues. These legends thus lend a mystical character to the world of women and their surroundings, simultaneously offering them ways of dealing with various problems that they faced in their everyday lives. A good example of such navigation can be found in those legends that deal with the consequences of tampering with land belonging to the huldufólk. A number of such legends can be found in the repertoires of the women under discussion here, such as the following account told by Bjarney Guðmundsdóttir (1893-1974):

He was called Hermann and really wanted to extend the house. Then a woman came to her [his wife], she dreamed of her [this woman], and begged her not to let him extend the house. She asked him not to, but he did it all the same, extended the house. And then the winter after, he lost 50 sheep, he lost all these sheep and left next spring. Then he moved out to Bjarnarnes and when he was doing the last trip [on the boat] with his wife and child, a 12- or 13-year-old boy, they got so sick that when they were off Barðsvik, he had to put them on shore. And they landed there. And then he went off, he went out and never came back. He was never seen again. (SÁM 89/2073)

As might be noticed, this legend, like others of a similar kind, has two axes of conflict rather than just one. The first reflects a conflict between the inhabitants of the farm and the supernatural, providing an implicit warning to audiences about the dangers associated with disrespecting such forces. The second conflict is more gendered and has a great deal to do with issues concerning the economic position of women and their overall lack of power with regard to decision-making. ${ }^{19}$ While women were certainly more closely associated with the domestic space of the farm than men, they nonetheless tended to have a subordinate role within the general social organization of the farm. Looking at these legends from this viewpoint, the roles of the supernatural woman and the housewife merge, the human woman becoming in a sense an extension of the former rather than an independent player in the legend, something that ultimately adds to the potential power of the housewife. Arguably, such legends can also be understood as providing a warning to men not to side-line their wife's opinions. For women in rural Iceland in the early 1900s, it might thus be argued that such legends, like the others discussed elsewhere in this chapter, supplied an effective means of giving voice to their hidden concerns about their surroundings. 


\section{CONCLUSION}

If we pull together the various spatial aspects involved in Icelandic women's legend-telling noted above, it is immediately evident that folk narrative archives, such as that used in this article, have the potential to provide valuable insights about the contextual surroundings of earlier storytelling, both directly and indirectly. Taking a spatially oriented approach to the narrative traditions of women in the past, like the one used here, is especially valuable considering the strong emphasis that scholars have historically tended to place on the storytelling of men. As this article has noted, while women in Iceland in the late nineteenth century and early 1900 s were largely confined to the farm in their everyday lives, they still had valuable social networks that extended beyond the domestic spaces of their homes and, in many cases, also proved to be comparatively mobile, among others as immigrants moving to new communities. In Iceland's rural community of the past, it is also clear that women played an important role within the transmission of oral narratives, as narrators who shared their narratives across different communities and as performers of narratives within the domestic space of the farms.

In short, while the Icelandic farm with its communal baðstofa in the late nineteenth century was essentially a central performance space for both men and women, this space was nonetheless evidently still influenced by gender and different gender roles reflected both in terms of who told narratives of different times, and the nature of the narratives told and the spaces they reflected. Evidently, the performance sessions that took place in the dark rökkrin period were quite different to those that occurred later in the evening, during the kvöldvaka. The rökkrin sessions were not only dominated by women's creativity and oral storytelling, but also involved a different, more intimate space in which only some residents of the household (mainly women and children) participated in the storytelling session. Women's storytelling performances thus seem to have taken place in more private settings than those that provided the context for men's performances. This might be said to bring us back to the familiar association between men and the public sphere and women and the private sphere, even though the boundaries in Iceland were clearly somewhat more blurred than those encountered elsewhere.

Finally, as has been shown above, gender-related differences can also be seen in the way Icelandic men and women in the past incorporated the spaces they themselves inhabited into their legend tradition. While the farm might have been the centre of economic and cultural production for both men and women, different gender roles and different spheres of activity meant that women had 
to some extent different experiences, knowledge, and perceptions of the farm and its surroundings from those experienced by men. Women's legends are noticeably more centred on the living space of the farm than those told by men. They also make both less and more complicated uses of the wilderness and other distant places in their legends, often combining them in some way with their own living spaces. In a similar way, it is evident that the most common supernatural themes in legends told by women are also those that are most directly connected to the farm in the traditional Icelandic world view. More often than not, these legends deal with problems that women faced in their daily lives within the domestic space at a time when the world order was still somewhat skewed against them. Arguably, these legends often also served to add a mystical layer to their daily living spaces, effectively transforming it to a new, more meaningful place. They were also a valuable means for women to express their feelings about their experiences, concerns, their dreams, and their discomfort with regard to the subordinate role they experienced within these spaces.

\section{NOTES}

1 This article follows the Icelandic custom of citing Icelandic authors by both first name and last name (patronym) and listing them alphabetically under their first names in the references.

2 This material will be referred to under its archive classification SÁM. These audio records (and many others) have been digitalized in recent years and are now available online as part of the Ísmús database (@ 2017) at http://www.ismus.is/.

3 In the article I will use the term "legends" broadly as a concept covering all realitybased narratives, including personal experience narratives, memorates, and joculates, which will all be treated as subcategories of the former.

4 See, for example, Ástríður Thorarensen (on Sigríður Jónsdóttir) (SÁM 92/3002); Guðbjörg Bjarman (on Porbjörg Guðmundsdóttir) (SÁM 89/1754); Halldóra Sigurðardóttir (on Puríour Guðmundsdóttir) (SÁM 85/219); Hulda Jónsdóttir (on Sigríður Jónatansdóttir) (SÁM 92/2991); Ingibjörg Finnsdóttir (on Guðrún Hannesdóttir) (SÁM 88/1561); Kristín Jensdóttir (on Guðrún Magnúsdóttir) (SÁM 89/1865); Kristín Jakobína Sigurðardóttir (on Guðrún Jónsdóttir (SÁM 90/2283); Porbjörg Guðmundsdóttir (on Guðríður Jóhannsdóttir) (SÁM 89/1761); Lilja Jóhannsdóttir (on Sigríður from Jörfi) (SÁM 92/2643); Sigurbjörn Snjólfsson (on Steinunn) (SÁM 92/2672); Porsteinn Porsteinsson (on Valgerður from Hoffell) (SÁM 85/237); and Puríður Björnsdóttir (on unnamed "old women“) (SÁM 89/1889). Storytelling by travelling women is also mentioned a few times in the answers to PP Questionnaire 7, in answers $\mathrm{DP} 428$, $\mathrm{PP} 439$, $\mathrm{PP} 454$ and ФР 463.

5 Translation of all quotes by Icelandic informants: Terry Gunnell. As underlined in this account, as in many others, orlofskonur clearly played a large role in the wonder tale 
tradition. This, nonetheless, does not mean that they did not tell legends as well, as one can see from Ástríour's remark about Guðrún's conversation with the householders. It is, of course, probable that the informants, most of whom were young children during the time when orlofskonur were still visiting, would have been more interested in wonder tales than legends.

6 On Icelandic migratory legends dealing primarily with female characters and women's experience, see, for example, Almqvist (2008) and Guðrún Bjartmarsdóttir (1982).

7 The two groups of women are distinguished entirely on the grounds of whether they settled down as adults in the region in which they grew up or outside these regions. Those women who settled down in their own childhood communities naturally often moved to new areas later in their lives, to nearby villages or to the capital of Reykjavík also, especially in old age when farms were passed on to children or new owners.

8 It is noteworthy that the female informants in the survey appear to have adopted considerably more legends into their own repertoires from female family members than from males. It is nonetheless not clear whether this was because women found legends told by other women more interesting and memorable than those told by men, or they were simply more exposed to legends told by their female family members. 165 of the 730 legends noted above were told by the women's mothers as opposed to only 112 that were heard from their fathers. 59 legends were learned from grandmothers as opposed to 34 learned from grandfathers, and 49 came from other female family members as opposed to 47 from other male family members (excluding husbands). Interestingly, the women's husbands are only cited as sources of 15 legends, which is somewhat surprising given the fact that over half of the women were widows at the time of the interviews, meaning that the husbands were no longer around to tell their own stories and maintain informal ownership over them.

9 Here the bias towards these non-related household members being women is clear. Non-family female household members are cited as the source of 49 legends as opposed to only 22 which were told by non-family males. This may be a reflection of the changing social reality in rural Iceland in the early 1900s, at a time when the industrialization of the fishing industry was creating new employment opportunities for men, leaving women as the dominant workforce in the agricultural sphere.

${ }^{10}$ Hallfreður Örn Eiríksson's sources include at least 57 accounts told by male and female informants, which appear to refer to storytelling taking place in the turf farm during rökkrin: SÁM 84/17; 84/22-23; 85/228; 85/247; 85/269; 85/272; 85/279; 85/284; $86 / 811 ; 86 / 820 ; 86 / 827 ; 86 / 845 ; 86 / 858 ; 86 / 875 ; 86 / 888 ; 88 / 1505 ; 88 / 1529 ; 88 / 1559$; $88 / 1561 ; 88 / 1571 ; 88 / 1575 ; 88 / 1631 ; 89 / 1717 ; 89 / 1719 ; 89 / 1770 ; 89 / 1784 ; 89 / 1793-94$; $89 / 1812 ; 89 / 1847 ; 89 / 1865 ; 89 / 1879 ; 89 / 1972 ; 89 / 2022 ; 89 / 2048 ; 90 / 2100 ; 90 / 2107$; 90/2111; 90/2211; 90/2246; 90/2283; 90/2306; 90/2329; 90/2349; 91/2370; 91/2426; 92/2639; 92/2675; 92/2736; 92/3002-03; 93/3380; 93/3510; 93/3534; and 93/3621. Not all of these accounts specify that the baðstofa was the storytelling space during rökkrin - all have thus been included here by default (unless any other place is specified).

${ }^{11}$ Of the 57 accounts on rökkrin storytelling, 37 refer to female narrators or female groups of narrators, some mentioned by name and others by gender-specific terms such as mothers, grandmothers, maids or orlofskonur, as opposed to only 10 accounts which include references to male narrators or a group of male narrators. 18 accounts include general references to narrators that are non-gender specific, making use of terms such as fólk (people) or gestir (guests). 
12 The huldufólk (lit. hidden people), sometimes referred to as álfar in Iceland, are the Icelandic equivalent of the Norwegian huldre or underjordiske (lit. underground people), the Irish and Scottish fairies and the Shetlandic trows. Similar in appearance and size to human beings, they are believed to live in rocks close the settlement areas. See further Gunnell 2007.

${ }^{13}$ See, for example, Einar Sigurfinnsson (SÁM 93/3621); Hulda Jónsdóttir (92/2991); Jóhanna Ólafsdóttir (SÁM 88/1571); Jóhanna Elín Ólafsdóttir (SÁM 89/1879); Sigríour Benediktsdóttir (SÁM 89/1720); Sigríđur Guðmundsdóttir (SÁM 89/2048); Sigurjón Jónsson (SÁM 84/23); Steinn Ásmundsson (SÁM 85/269).

${ }^{14}$ In the accounts, legends about ghosts are noted as being frequently told 24 times and legends about huldufólk 18 times.

${ }^{15}$ While these sources as well as the answers concerning the kvöldvaka in Questionnaire 7 appear to largely underline the role of men as the main performers during the $k v o ̈ l d v a k a$, it is nonetheless clear that some women certainly did assume this role, not least during the period from January to spring, when, as noted above, many men were away during the fishing season. One informant of Hallfreður Örn's, Kristín Jakobína Sigurðardóttir (SÁM 90/2287), notes, for example, that while women generally rarely read out loud during the kvöldvaka because of the background noise, her sister, who was considered an exceptionally good reader, did sometimes take on this role. It is also clear that on some farms, children would read during the kvöldvaka in order to practise their reading skills (Magnús Gíslason 1977: 95).

${ }^{16}$ In his analysis of the Icelandic kvöldvaka (based on the earlier-noted questionnaire), Magnús Gíslason (1977: 144) suggests that the telling of oral narratives, including both wonder tales and legends, was a common activity at this time. Hallfreður Örn's sources, however, do not support this claim. As suggested above, most informants appear to assign this kind of oral storytelling to rökkrin rather than to the kvöldvaka itself. Oral storytelling during the kvöldvaka is only mentioned in about 15 of Hallfreður Örn's accounts. 250 accounts mention the reading of stories aloud during the kvöldvaka.

${ }^{17}$ It is noteworthy that the narrator Guðrún Jóhannsdóttir (1897-1987), for example, tells seven such multi-spatial narratives connecting her adult home in Skarðströnd in western Iceland with her childhood home in Grindavík on the Reykjanes Peninsula more than 200 kilometres away (SÁM 88/1902; 88/1706; 89/2010; 92/2580-81). As underlined by Heijnen's study on Icelandic dream narratives (see Heijnen 2013), Icelanders tend to see dreams as a form of reality and means of receiving communications from the dead and other supernatural beings or of gaining knowledge about future events. According to a recent survey on Icelandic belief (2006/2007), 36\% of men and $41 \%$ of women claimed they had gained knowledge about future events from their dreams; about $90 \%$ ( $86 \%$ of men and $94 \%$ of women) believed such prophetic dreams were possible (see Ásdís Aðalbjörg Arnalds \& Ragna Benedikta Garðarsdóttir \& Unnur Diljá Teitsdóttir 2008: 16, 79).

${ }^{18}$ For a slightly different approach to the relationship between space, storytellers, and the supernatural in legends, see Broadwell and Tangherlini's "Ghostscape" (2017).

${ }^{19}$ Until 1923, husbands had autonomy over Icelandic farms, even when the farm had belonged to their wives before marriage. Women nonetheless gained a limited degree of autonomy over the farms in 1900 when new laws stated that while the husband 
would have the autonomy over the farm, he could not sell it or mortgage it without his wife's consent (Erla Hulda Halldórsdóttir \& Guðrún Dís Jónatansdóttir 1998: 147, 150).

\section{ARCHIVAL SOURCES}

PP: Pjóðháttadeild Pjóðminjasafns Íslands [Ethnological Collections] 1962. Questionaire 7: Kvöldvakan og hlutdeild heimilisins i íslensku pjóðaruppeldi. [On Evening Wakes.] On Sarpur: Menningarsögulegt gagnasafn [The Database of Icelandic Museums]. N.d. Consortium of Icelandic Libraries, available at http://sarpur.is/, last accessed on 28 July 2021.

SÁM: Segulbandasafn Stofnunar Árna Magnússonar í Íslenskum fræðum 2017. [The Sound Archives of Árni Magnússon Institute in Icelandic Studies]. Ísmús@, available at https://www.ismus.is/, last accessed on 28 July 2021.

\section{REFERENCES}

Almqvist, Bo 2008. Midwife to the Fairies (ML 5070) in Icelandic Tradition. In: Terry Gunnell (ed.) Legends and Landscape: Articles Based on Plenary Papers Presented at the 5th Celtic-Nordic-Baltic Folklore Symposium, Reykjavik 2005. Reykjavík: University of Iceland Press, pp. 273-342.

Anna Lísa Rúnarsdóttir 2007. Á tímum torfbæja: Hýbýlahættir og efnismenning $i$ íslenskum torfbæjum frá 1850. [In the Time of the Turf Farm: Ways of Life and Material Culture on Icelandic Turf Farms from 1850.] Skýrslur bjóðminjasafns Íslands 2007/1. Reykjavík: Pjóðminjasafn Íslands. Available at http://www. thjodminjasafn.is/media/rannsoknir/Torfbaejarskyrsla-PDF.pdf, last accessed on 29 July 2021.

Ásdís Aðalbjörg Arnalds \& Ragna Benedikta Garðarsdóttir \& Unnur Diljá Teitsdóttir 2008. Könnun á íslenskri bjóðtrú og trúarviðhorfum. [A Survey of Icelandic Folk Beliefs and Belief Attitudes.] Reykjavík: Félagsvísindastofnun Háskóla Íslands. Available at https://notendur.hi.is/terry/articles/Thjodtruakonnun\%202008.pdf, last accessed on 29 July 2021.

Björn Magnússon 1970. Vestur-Skaftfellingar 1703-1966: Er skráðir fundust á skjölum og bókum. [The People of West-Skaftafell 1703-1966: On the Basis of Records and Books.] Vol. I. Reykjavík: Prentsmiðjan Leiftur.

Boucher, Alan (ed.) 1989. The Iceland Traveller: A Hundred Years of Adventure. Reykjavík: Iceland Review.

Broadwell, Peter M. \& Tangherlini, Timothy R. 2017. GhostScope: Conceptual Mapping of Supernatural Phenomena in a Large Folklore Corpus. In: Ralph Kenna \& Máirín MacCarron \& Pádraig MacCarron (eds.) Maths Meets Myths: Quantitative Approaches to Ancient Narratives. Switzerland: Springer International Publishing, pp. 131-157. https://doi.org/10.1007/978-3-319-39445-9. 
Dégh, Linda 2001. Legend and Belief: Dialectics of Folklore Genre. Bloomington \& Indianapolis: Indiana University Press.

Einar Ólafur Sveinsson 2003. The Folk-Stories of Iceland. Rev. by Einar G. Pétursson, transl. by Benedikt Benedikz, ed. by Anthony Faulkes. Text series: Viking Society for Northern Research 16. London: Viking Society for Northern Research.

Erla Hulda Halldórsdóttir \& Guðrún Dís Jónatansdóttir (eds.) 1998. Ártöl og áfangar $i$ sögu íslenskra kvenna. [Key Dates and Key Developments in the History of Icelandic Women.] Reykjavík: Kvennasögusafn Íslands. Available at https://baekur. is/bok/000021526/Artol_og_afangar_i_sogu, last accessed on 29 July 2021.

Guðmundur Hálfdanarson 2008. Private Spaces and Private Lives: Privacy, Intimacy, and Culture in Icelandic 19th-Century Rural Homes. In: Pieter François \& Taina Syrjämaa \& Henri Terho (eds.) Power and Culture: New Perspectives on Spatiality in European History. Pisa: Plus-Pisa University Press, pp. 109-128.

Guðmundur Jónsson \& Magnús S. Magnússon (eds.) 1997. Hagskinna: Sögulegar hagtölur um Ísland / Icelandic Historical Statistics. Reykjavík: Hagstofa Íslands.

Guðmundur Ólafsson \& Hörður Ágústsson 2004. The Reconstructed Medieval Farm in Pjórsárdalur and the Development of the Icelandic Turf House. Transl. by Keneva Kunz. Reykjavík: National Museum of Iceland \& Landsvirkjun.

Guðrún Bjartmarsdóttir 1982. Ljúflingar og fleira fólk: Um formgerð, hugmyndafræði og hlutverk íslenskra huldufólkssagna. ["Sweety Boys" and Other Beings: On the Forms, Ideology and Role of Icelandic Legends Dealing with the "Hidden People".] Tímarit máls og menningar, Vol. 43, No. 3, pp. 319-336.

Gunnar Karlsson 2000. Iceland's 1100 Years: The History of a Marginal Society. London: Hurst \& Co.

Gunnell, Terry 2002. “Komi peir sem koma vilja ...“: Sagnir um innrás óvætta á jólum til forna á íslenska sveitabæi. [„Come all those who wish to come...“: Legends Concerning the Attacks on Icelandic Farmhouses Made by Spirits at Christmas.] In: Baldur Hafstað \& Haraldur Bessason (eds.) Úr manna minnum: Greinar um islenskar bjóðsögur. Reykjavík: Heimskringla, pp. 191-209.

Gunnell, Terry 2004. The Coming of the Christmas Visitors: Folk Legends Concerning the Attacks on Icelandic Farmhouses Made by Spirits at Christmas. Northern Studies, Vol. 38, pp. 51-75. Available at https://www.academia.edu/2993263/, last accessed on 29 July 2021.

Gunnell, Terry 2006. Narratives, Space and Drama: Essential Spatial Aspects Involved in the Performance and Reception of Oral Narrative. Folklore: Electronic Journal of Folklore, Vol. 33, pp. 7-25. http://dx.doi.org/10.7592/FEJF2006.33.terry.

Gunnell, Terry 2007. How Elvish Were the Álfar. In: Andrew Wawn \& Graham Johnson \& John Walter (eds.) Constructing Nations, Reconstructing Myth: Essays in Honour of T. A. Shippey. Turnhout: Brepols, pp. 111-130. https://doi.org/10.1484/M. MMAGES-EB.3.3608.

Gunnell, Terry 2012. Waking the Dead: Folk Legends Concerning Magicians and Walking Corpses in Iceland. In: Merril Kaplan \& Timothy R. Tangherlini (eds.) News from Other Worlds: Studies in Nordic Folklore, Mythology and Culture: In Honor of John F. Lindow. Berkeley \& Los Angeles: North Pinehurst Press, pp. 235-266. 
Gunnell, Terry 2016. Sagnagrunnur: En kartlagt database over de islandske folkesagn. [Sagnagrunnur: A Mapped Database of Icelandic Legends.] Saga och sed: Kungl. Gustav Adolfs akademiens årsbok. 2015, pp. 15-40. Available at https://kgaa. bokorder.se/en-us/download/162c2858-749e-4211-bab6-e887b3086563, last accessed on 29 July 2021.

Gunnell, Terry 2018. The Power in the Place: Icelandic Álagablettir Legends in a Comparative Context. In: Ülo Valk \& Daniel Sävborg (eds.) Storied and Supernatural Places: Studies in Spatial and Social Dimensions of Folklore and Sagas. Studia Fennica Folkloristica 23. Helsinki: Finnish Literature Society, pp. 27-41.

Gunnell, Terry \& Oring, Elliot \& Klein, Barbro \& Lindow, John \& Weiss, Haim \& Valk, Ülo \& Tangherlini, Timothy R. \& Skott, Fredrik 2013. Discussion: Why Should Folklore Students Study "Dead" Legends? ARV: Nordic Yearbook of Folklore, Vol. 69, pp. 171-209. Available at https://kgaa.bokorder.se/en-us/download/ e80947af-d6ee-427c-88c2-9d5193f2b056, last accessed on 29 July 2021.

Hastrup, Kirsten 1990. Nature and Policy in Iceland 1400-1800: An Anthropological Analysis of History and Mentality. Oxford: Clarendon Press.

Heijnen, Adriënne 2013. The Social Life of Dreams: A Thousand Years of Negotiated Meanings in Iceland. European Studies in Culture and Policy, Vol. 12. Berlin: LIT. Hjördís Sigursteinsdóttir \& Guðbjörg Linda Rafnsdóttir 2009. The Position of Women in Agriculture: A Gender Perspective / Staða kvenna í landbúnaði: Kynjafræðilegur sjónarhóll. Stjórnmál og stjórnsýsla, Vol. 5, No. 1, pp. 27-48. https://doi. org/10.13177/irpa.a.2009.5.1.2.

Hjörleifur Stefánsson 2013. Af jörðu: Íslensk torfhús. [From the Earth: The Icelandic Turf House.] Reykjavík: Crymogea.

Honko, Lauri 1989. Methods in Folk Narrative Research. In: Reimund Kvideland \& Henning K. Sehmsdorf \& Elizabeth Simpson (eds.) Nordic Folklore: Recent Studies. Bloomington \& Indiapolis: Indiana University Press, pp. 23-39.

Jón M. Ívarsson 2007. Vormenn Íslands: Saga UMFÍ $i 100$ ár. [The History of the Icelandic Youth Movement Over 100 Years.] Reykjavík: Ungmennafélag Íslands.

Jónas Jónasson 2010. Íslenzkir bjóðhættir. [Icelandic Ways of Life.] 4th edition. Edited by Einar Ól. Sveinsson. Reykjavík: Opna.

Júlíana Póra Magnúsdóttir 2008a. Huldufólk á faraldsfæti: Frásagnir briggja kvenna af samskiptum við huldufólk. [The Hidden People on the Move: Accounts by Three Women Telling of Their Contacts with the Hidden People.] In: Gunnar Pór Jóhannesson \& Helga Björnsdóttir (eds.) Rannsóknir í félagsvísindum IX: Félagsog mannvísindadeild, félagsráðgjafardeild, sálfræðideild og stjórnmálafræðideild. Reykjavík: Félagsvísindastofnun Háskóla Íslands, pp. 753-763. Available at http://hdl.handle.net/1946/7639, last accessed on 29 July 2021.

Júlíana Póra Magnúsdóttir 2008b. Saga til næsta bæjar: Sagnir, samfélag og bjóðtrú sagnafólks frá austurhéraði Vestur-Skaftafellssýslu. [A Story Worth Hearing: The Legends, Society and Folk Beliefs of Storytellers of the Eastern Part of West Skaftafell.] Unpublished MA Thesis, University of Iceland. 
Júlíana Póra Magnúsdóttir 2018. Gender, Legend, and the Icelandic Countryside in the Long Nineteenth Century: Re-engaging the Archives as a Means of Giving Voice to the Women of the Past. Folklore, Vol. 129, No. 2, pp. 129-147. https://doi.org /10.1080/0015587X.2018.1439604.

Loftur Guttormsson 2008. Sjálfsprottnir skólar. [Independent Schools.] In: Loftur Guttormsson (ed.) Almenningsfræðsla á Íslandi 1880-2007. Vol. 1: Skólahald í bæ og sveit 1880-1945. Reykjavík: Háskólaútgáfan, pp. 56-71.

Magnús Gíslason 1977. Kvällsvaka: En isländsk kulturtradition belyst genom studier $i$ bondebefolkningens vardagsliv och miljö under senare hälften av 1800-talet och början av 1900-talet. [The Evening Wake: An Icelandic Tradition Described on the Basis of Studies into the Daily Life and Environment of Farmers in the 1800 s and Start of the 1900s.] Acta Universitatis Upsaliensis. Studia ethnologica Upsaliensia 2. Uppsala: Uppsala universitet; Stockholm: Almqvist \& Wiksell.

Ragnheiður Ólafsdóttir 2008. "Pride and Prejudice": The Preservation of the Icelandic Rimur Tradition. Yearbook for Traditional Music, Vol. 40, pp. 104-116. Available at http://www.ictmusic.org/yearbook/yearbook-traditional-music-vol-40-2008, last accessed on 18 October 2021.

Rósa Porsteinsdóttir 2011. Sagan upp á hvern mann: Átta íslenskir sagnamenn og ævintýrin peirra. [Retelling Tales: Eight Icelandic Storytellers and their Wonder Tales.] Reykjavík: Stofnun Árna Magnússonar í íslenskum fræðum.

Rósa Porsteinsdóttir 2015. "Ég kann langar sögur um kónga og drottningar" [”I Know Some Long Stories about Kings and Queens"]: Eight Icelandic Storytellers and Their Fairy Tales. ARV: Nordic Yearbook of Folklore, Vol. 71, pp. 67-98. Available at https://www.academia.edu/24443529/, last accessed on 29 July 2021.

Schechner, Richard 2006. Performance Studies: An Introduction. 2nd edition. London $\&$ New York: Routledge.

Skott, Fredrik 2008. Folkets minnen: Traditionsinsamling $i$ idé och praktik 1919-1964. [The Memory of the People: The Collection of Traditions in Thought and Practice 1919-1964.] Avhandlingar från Historiska institutionen i Göteborg, Vol. 53. Göteborg: Institutet för språk och folkminnen samt Göteborgs universitet.

Tangherlini, Timothy R. 1994. Interpreting Legend: Danish Storytellers and Their Repertoires. New York: Garland.

Tangherlini, Timothy R. (ed. \& transl.) 2013. Danish Folktales, Legends and Other Stories. Seattle: University of Washington Press.

Trausti Dagsson 2014. Landfræðileg kortlagning á íslenskum sögnum. [The Geographic Mapping of Icelandic Folk Legends.] In: Helga Ólafs \& Thamar M. Heijstra (eds.) Pjóðarspegillinn XV: Rannsóknir í félagsvísindum. Félags- og mannvísindadeild. Reykjavík: Félagsvísindastofnun Háskóla Íslands, pp. 1-11. Available at http:// hdl.handle.net/1946/19992, last accessed on 29 July 2021.

Tuan, Yi-Fu 1977. Space and Place: The Perspective of Experience. Minneapolis \& London: University of Minnesota Press. 
Júlíana Th. Magnúsdóttir is pursuing a $\mathrm{PhD}$ at the Department of Folkloristics and Museum Studies at the University of Iceland and works as adjunct teacher at the same department. Her PhD thesis deals with legend tradition of Icelandic women born in the latter part of the nineteenth century and their relationship with women's experiences, spaces, and social conditions.

jthm2@hi.is 